with the methods and types of bibliographical description, documentary reproduction, etc., and will include training in multilingual bibliographical terminology.

A series of seminars on (3) the library will be divided quite conventionally into sections on book selection; classification, subject heading; and cataloging; service, and administration.

The seminar on (4) reading will deal with the part which libraries play or should play in the diffusion of knowledge and in education.

The seminar on (5) the book trade will deal with some basic problems of publishing and bookselling, with special emphasis on the librarian's relationship to these trades.

The seminars will in no sense be survey courses. Rather they will be devoted to specific problems or topics within the subjects covered and the coverage will vary from year to year. It is our contention that a thorough knowledge of research and research methods within a few segments of each proposed subject will be more valuable than a superficial coverage of entire fields. It is also felt that, in order to make the seminars provocative and to create a true interest in the topics treated, every effort should be made to prevent the forming of instructional patterns such as develop so easily when teaching becomes repetitious and standardized.

At the end of the two-year period of ap- prenticeship and instruction a comprehensive examination will be given to test ability and attitude. Upon the successful passing of this examination the trainees will be accepted as professional members of the University of Pennsylvania Library staff or will be recommended as professionally competent for employment in other institutions. Though they will not be awarded degrees, they will receive a written statement or possibly a formal certificate stating training and accomplishments. Exceptionally qualified and more mature students might be granted professional rating after a single year, even though continuing to attend courses, or they might be granted permission to substitute during the second year, graduate courses in a subject field in which they have specialized or desire to specialize.

The program as outlined here, to prove successful depends in no small part upon our wisdom in planning. We are only too aware of the difficulties which will have to be overcome in order to make this experiment a success. They are :

I. Can we find graduates of accepted colleges and universities who will meet the high standards set and who are interested in becoming candidates?

2. Will instruction be successful, in accordance with specifications set forth in this paper?

3. Will we be able to place our trainees, once they have passed our examination, in professional positions in other institutions as well as in the library of the University of Pennsylvania?

\title{
Education for Librarianship on Trial: A Discussion
}

The preceding two papers leave me little to do but agree with them and to apologize to the writers because it was necessary for them to curtail their own statements in order to save time for a third person to review them. That being the case, I am going to 
omit any blow-by-blow comment on the papers, while I hurry on to suggest a few points which the writers themselves may be willing to amplify later.

Mr. Metcalf is inclined to think that, "We have been apt to blame our library schools too much and ourselves too little" for the state of affairs existing in training for librarianship. Very true, I believe. We practicing librarians seem to have gone on insisting on "getting the work done" and have continued to look to the library schools to supply us with the necessary workers. These candidates, according to the questions I am asked to answer about applicants applying for admission to our library schools, are not being judged very closely on their intellectual attainments. What we seem to have indicated as desirable are neat, accurate, tactful paragons of initiative, who are also as good mixers as Rotarians; bright, cheerful buttons on the library cap; docile workers at too many mechanical tasks; responsible drudges of sufficient physical stamina not to grow tired or ill or out of humor. All this, and heaven too, in the good old days, for $\$ 1350$ a year in youth; in middle age, $\$ 2500$ had to be stretched to provide an annuity for old age. No wonder the time has come to rethink education for librarianship!

It has interested me very much to speculate about how we got off on this foot in setting up our programs in library schools. And I have wondered if the concept of the library as a sort of factory full of efficient technicians might not have resulted from the industrial revolution that was going on in the United States in the I880's and I89o's. All education derives its content from the civilization of which it is a part and takes its direction from the demands made upon its educated citizens. Greek education of Plato's time and education in Chaucer's England are two examples of this truth that at once come to mind. May it not be significant that when formal training for librarianship began to be offered in the two final decades of the last century the country was in a great expansion of technological achievement-steel, railroads, mines, all busy changing our civilization from an agrarian to an industrial economy-and that this development was accompanied by a belief in science as a worker of miracles? Granted that techniques are a by-product of science and not science itself, it is still easy to see how training for librarianship might have sought to correct chaotic muddling in libraries by falling in line with the general emphasis upon technical improvement which was glorified at the time. If that is at all the case, we need not waste time condemning the training provided in the past, when the technical emphasis was inescapable, but only welcome with enthusiasm the changes foretold by such discussions as those in which we are engaged today.

\section{Tribute to Past Librarians}

As we applaud the new approaches being made to recruiting, selecting, and training librarians of the future, let us pause to pay tribute to those trained in the past. Our hearty thanks are due them for the backbreaking load they have carried for the libraries of this country. Whatever fair ideals of librarianship we build into living realities in the future, the work of these past and present librarians, technically trained or not, will be the foundation on which that dream will rest. With all its sins of omission and commission, education for librarianship already has produced a fair share of able people, with a leaven of those who are very able. Let us see to it, then, that in our plans for the future we keep clearly in mind the right earned by the librarians of the present to opportunities to become better ones. 


\section{Favors Pennsylvania's Plan}

Mr. Hirsch describes an apprenticeship that places responsibility on librarians of scholarship and ability for developing the good raw material on the staff into finished products who will become librarians of distinction. This delights me, since I have long lamented in librarianship the lack of one of the most admirable traits in members of academic faculties: their assumption of responsibility for pulling and pushing their young assistants of promise through the necessary disciplines until these assistants emerge as full-fledged colleagues. More than one dean of a school of librarianship has spoken to me bitterly of sending out from the school able, enthusiastic, keen graduates, only to find these same people in a few years tired, disillusioned, and disaffected. One such dean, a man of more sincerity than urbanity, said while pointing an accusing finger in my direction, "Their backs have been broken by old battle-axes." Well, perhaps here endeth the old battle-ax tradition, and here beginneth a tradition of college and university libraries as the breeding ground of those scholar-librarians who, with or without formal training in schools of librarianship, will be in the future as they have in the past, ornaments to the profession made in the image of such men as Wilberforce Eames and Richard Garnett.

\section{Librarians Not Mere Technicians}

Both Mr. Metcalf and Mr. Hirsch, by implication, call for a new definition of what librarians should know in order to do what they should do and be what they should be. This seems to me the crux of the whole thing. If we are not mere technicians-and this whole discussion is predicated on the belief that we are not-then we are educators who believe in education as designed to teach people how to read and who believe that the real university is in- deed a collection of books. With all our faults and imperfections most of us do know how to read and how to use books. If only we had had the courage of our own convictions and had prepared ourselves as educators, not as technicians, we could by making the library the center of the educational program of the college, have achieved for our institutions most of the important values now being rediscovered elaborately through such devices as honors work, the general examination, and this or that other new plan. The other day I was testing myself by the "Literary I.Q." in the Saturday Review of Literature when I came upon the following quotation: "I am well aware that I am the 'umblest person going. My mother is likewise a very 'umble person. We live in an 'umble abode." Perhaps librarians have a touch of Mr. Uriah Heep's philosophy concerning the value of humility. Well, it seems to me time to ask a great deal more of our own scholarship, but at the same time to expect that scholarship to play its part in the renaissance of liberal education in the United States that would result if the libraries we conduct were made the living, breathing part of the educational program they should be.

In illustration of belief in libraries as the verso of the same leaf of which the classroom is the recto, I find very heartening the recent celebration at Yale of the return of the university collections to peacetime use. And I cannot refrain from quoting here a comment on that occasion in the London Times which reads:

The relationship between things and ideas constantly engages the attention of the more thoughtful custodians of the former.... And Yale's lively sense of the active, as distinct from the merely conservative, function of an institution towards its collections, whether of books or prints or scientific objects, was ... clearly visible. ... But the event has a more than merely domestic significance . . . for 
Professor Tinker exemplifies in his field that attitude towards things in libraries and museums which Mr. (now Dr.) Ivins has extolled and practised in his-the attitude of a man breathing life into dead bones. ${ }^{1}$

I take it that our in-service programs look to the discovery of the Tinkers and Ivinses of the college and university libraries of the future, who will inevitably be educators rather than custodians.

\section{Specialists Need Training}

Mr. Metcalf speaks of the superior recognition "rightly or wrongly" given to librarians specializing in administration. I believe that "wrongly" is the word to apply to the habit that has grown up of glorifying the general administrative work done by the head of a library, and I hope the time will come when the administrator will be the chairman of a group of equals, as the head of an academic department of instruction is now the administrative officer of a group of professors of equal rank. Heartily as I believe in Mr. Metcalf's suggestion, which I assume to mean that university training in theoretical public administration shall be given to librarians who will be the potential directors of libraries, this seems to me less important than the training we provide for our bibliographers, research consultants, subject specialists, and what, for lack of a better term, may be called specialists in the book arts. All librarians doing this latter type of work depend for their worth on a large body of factual knowledge. An administrator, if naturally endowed with common sense, judgment, humanity, and "risktaking ability," often comes through splendidly without any theoretical instruction at all. This statement is not intended to disparage training in the theory of public administration, which is one of the most promising ideas now at work among us. It can-

\footnotetext{
${ }^{1}$ London Times Literary Supplement, Nov. 9, 1946, p. 556 .
}

not, however, supply native endowment, which is at the heart of administrative success. But no amount of native endowment can provide subject knowledge in music, fine arts, philosophy, and all the other subjects in a liberal arts curriculum, of which knowledge is necessary for successful selection and use of books in support of the educational program of the institution. It is the training of the people who do this sort of work that concerns me, because I believe that as Spinoza was intoxicated by the intellectual love of God, so librarians must be intoxicated by the love of knowledge and of books before they are able really to enter into the heart of the library matter.

We have seen numerous good administrators in libraries who transferred to their posts after being trained as lawyers, teachers, historians, and artists. Even poets have occupied high administrative posts in libraries! But I believe that what we are feeling after in all of these discussions is the humanistically trained man or woman who is book-minded and whom we have failed to educate in sufficient numbers in our schools. For this reason, I disagree with Mr. Danton when he reserves his third or upper level of training for the administrative specialists. $^{2}$ For training at the highest level I should like a three-year program of studies arranged to provide excellent knowledge of foreign languages, wide study in two or three related fields, which would provide in graduate work something resembling the undergraduate interdepartmental major, a series of well-developed courses in the book arts, and the whole thing held together by training in what $\mathrm{Mr}$. Hirsch calls documentation, or what some of us mean when we say "bibliography." This latter training would be given perhaps by the library of

(Continued on page 160 )

\footnotetext{
2 Danton, J. P. Education for Librarianship: Criti. cism, Dilemmas, and Proposals. School of Library Service, Columbia University, 1946, p. 26.
} 
But in every case the loan is made to a library and it is the borrowing library that is responsible for the safety of the material.

Of course, the objection may be made that nothing so far expressed has considered the problem from the borrower's point of view. Assuming that a professor needs books not to be found in his own library, how can he obtain them without imposing an impossible burden on himself and also on some other library?

In the case of any institution where constant publication on the part of faculty members is compulsory - that is, necessary for tenure-the administration should set aside a fund to defray the expense of interlibrary loan. Whether this should be part of the library fund or that of the departments, and how it should be apportioned, are matters of individual policy.

When the work in question is solely for the professor's own benefit, it seems not only fair but advisable that he pay the cost. In the case of work for a degree, the books should always be requested first from the university where he is enrolled, and no other library should be appealed to until that one has been tried.

\section{Regional Agreements}

For the rest, it may well be that regional agreements among the libraries of a given locality may be the answer. These agreements might well cover such matters as avoidance of duplication of purchase and union catalogs, as well as interlibrary loan. An example of such an arrangement is that between the libraries of Duke University and the University of North Carolina. These libraries not only have union catalogs of each others' collections with mutual lending, but there is a truck service between the two to hasten deliveries. Some such understanding is now under consideration for the college libraries of South Carolina, though at present it has not progressed beyond the nebulous stage of discussion and conference.

\section{Education for Librarianship}

\section{(Continued from page I3I)}

the university concerned. If the "deans within deans" who manage our graduate schools are not willing to honor such a program by a degree, can we not accept a statement of work done and take the lead in selecting the first-class article that we want, on its merits and not for its tag?

It seems to me that we now have a very helpful body of literature before us on education for librarianship. To this, Mr. Danton's interesting pamphlet is an excellent guide. Let us hope that discussion to follow, and future publications as well, will keep open the question of in-service training, so that it may be thoroughly tried. We already have available to us fruitful suggestions for a greater division of labor in libraries and for better use of clerical help derived from high school and junior colleges. These and other devices for reducing costs will be very necessary if we are to provide adequate salaries for much more highly trained people. Then, if we permit all of this thought and writing and talking to bog down without good results, we shall doubtless continue to fail to bring our libraries into proper focus at the center of liberal education provided in our institutions; and we shall at least partially justify the all too common misconception of our function that classes us as housekeepers of books rather than with educators who teach not in a classroom but through the conduct of a library. 